\title{
Assessing the Impact on Virus Transmission and Insect Vector Behavior of a Viral Mixed Infection in Melon
}

\author{
Maria Luisa Domingo-Calap, ${ }^{1}$ Ana Beatriz Moreno, ${ }^{1}$ Juan Antonio Díaz Pendón, ${ }^{2}$ Aranzazu Moreno, ${ }^{3}$ \\ Alberto Fereres, ${ }^{3}$ and Juan José López-Moya ${ }^{1,4, \dagger}$ \\ ${ }^{1}$ Centre for Research in Agricultural Genomics (CRAG), Consejo Superior de Investigaciones Científicas (CSIC)-IRTA-UAB-UB, Cerdanyola \\ del Vallès, Barcelona, Spain \\ 2 Institute for Mediterranean and Subtropical Horticulture "La Mayora" (IHSM-UMA-CSIC), Algarrobo-Costa, Málaga, Spain \\ ${ }^{3}$ Institute of Agricultural Sciences, ICA, CSIC, Madrid, Spain \\ ${ }^{4}$ CSIC, Barcelona, Spain \\ Accepted for publication 9 September 2019.
}

\begin{abstract}
Mixed viral infections in plants are common, and can result in synergistic or antagonistic interactions. Except in complex diseases with severe symptoms, mixed infections frequently remain unnoticed, and their impact on insect vector transmission is largely unknown. In this study, we considered mixed infections of two unrelated viruses commonly found in melon plants, the crinivirus cucurbit yellow stunting disorder virus (CYSDV) and the potyvirus watermelon mosaic virus (WMV), and evaluated their vector transmission by whiteflies and aphids, respectively. Their dynamics of accumulation was analyzed until 60 days postinoculation (dpi) in mixed-infected plants, documenting reduced titers of WMV and much higher titers of CYSDV compared with single infections. At $24 \mathrm{dpi}$, corresponding to the peak of CYSDV accumulation, similar whitefly transmission rates were obtained when comparing either individual or mixed-infected plants as CYSDV sources, although its
\end{abstract}

ABSTRACT

Plant viruses are distributed worldwide and have a significant impact on plant health and crop production (Alexander et al. 2014). Transmission to susceptible hosts is a key step in their cycles, which rely mainly on the activity of insect vectors (Whitfield et al. 2015). Considering the important ecological roles played by viruses, their relationships with hosts and organisms acting as vectors are increasingly being explored (Eigenbrode et al. 2002; Mauck et al. 2010; Mauck et al. 2015b). Indeed, recent reports documented cases in which plant viruses can manipulate their hosts and, consequently, modify the attractiveness and palatability for vectors in ways that modulate transmission (Mauck et al. 2012; Peñaflor et al. 2016), inducing changes in host morphology or physiology (Culver and Padmanabhan 2007), or manipulating vector behavior (Lefèvre et al. 2009; Mauck 2016; Mauck et al. 2018). Observed effects include modification of host defense responses (Petek et al. 2014;

†Corresponding author: J. J. López-Moya; juanjose.lopez@cragenomica.es

Funding: M. L. Domingo-Calap and A. B. Moreno were recipients of FPI contract BES-2014-068970 from Ministerio de Economía y Competitividad and H2020 Marie Skłodowska-Curie Actions IF fellowship H2020-MSCA-IF-2014 SEP-210187550 from the European Union, respectively. Work was financed by Ministerio de Economía y Competitividad grants AGL2013-42537-R and AGL2016-75529-R to J. J. López-Moya and J. A. Díaz Pendón, AGL2013-47603-C2-2-R to A. Fereres, FEDER funds, and support to CRAG from "Severo Ochoa programme" SEV2015-0533 and from Generalitat de Catalunya CERCA Institution.

*The $\boldsymbol{e}$-Xtra logo stands for "electronic extra" and indicates that one supplementary figure and five supplementary tables are published online.

The author(s) declare no conflict of interest.

(C) 2020 The American Phytopathological Society secondary dissemination was slightly biased toward plants previously infected with WMV, regardless of the source plant. However, at later time points, mixed-infected plants partially recovered from the initially severe symptoms, and CYSDV transmission became significantly higher. Interestingly, aphid transmission rates both at early and late time points were unaltered when WMV was acquired from mixed-infected plants despite its reduced accumulation. This lack of correlation between WMV accumulation and transmission could result from compensatory effects observed in the analysis of the aphid feeding behavior by electrical penetration graphs. Thus, our results showed that mixed-infected plants could provide advantages for both viruses, directly favoring CYSDV dissemination while maintaining WMV transmission.

Keyword: virology
Zhang et al. 2012), changes in the nutritional quality of the plant (Alexander et al. 2014; Su et al. 2015), or alterations of visual traits and production of volatiles conditioning attraction (Ingwell et al. 2012; Liu et al. 2013). Because transmission to new hosts determines, in part, the fitness of the pathogen, vector performance may have a direct impact on the ecology and evolution of the viruses they transmit (Gutiérrez et al. 2013; Stafford et al. 2011).

Nevertheless, our understanding of how such interactions function in complex ecological environments is still limited. Plants frequently interact with multiple pathogens simultaneously, and the composition and dynamics of ecological communities can be significantly affected (Mauck et al. 2015a,b; Stout et al. 2006). In particular, mixed infections of plant viruses are common, and current evidence suggests that mixed infections are the rule and not the exception in nature (DaPalma et al. 2010; Mascia and Gallitelli 2016; Roossinck et al. 2015). In addition, several important viral diseases of plants are the outcome of interactions between multiple viral agents (Syller 2012).

In nature, viral mixed infections can be generated by the transmission of different viruses by different vectors, or by the same vector carrying the different viruses (Syller 2014). The result of a mixed infection varies according to the type of interaction between the viruses involved, from synergism to antagonism (Mascia and Gallitelli 2016; Syller 2012). In a synergistic interaction, at least one of the viruses benefits from the presence of the others. The benefit is often quantifiable as an increase in the viral titer and, consequently, the resulting symptoms may be more severe compared with a single infection. In contrast, during an antagonistic interaction, the presence of more than one virus is detrimental to at least one of them, and this is often reflected in a decrease of the viral titer. The order of infection also influences the 
outcome in virulence and titers (Chávez-Calvillo et al. 2016; Saldaña et al. 2003).

Few studies have explored mixed viral infections with respect to their effects on host-pathogen-vector relationships in agricultural systems (Salvaudon et al. 2013; Syller 2012; Syller and Grupa 2016). Here, we focused on a mixed viral infection to shed light on the possible ecological outcomes regarding vector transmission. The work was carried out in melon (Cucumis melo L.), an economically important crop with global production of close to 30 million tons in 2016 (http://www.fao.org/home/en/). As in other crops, a significant part of the potential production of melon could be lost due to diseases caused by diverse pathogens, including viruses (Oerke 2006). Moreover, field surveys have reported high occurrence of multiple viral infections in melon and other cucurbits (Juarez et al. 2013). Here, we focused on two viruses that frequently infect melon: the crinivirus cucurbit yellow stunting disorder virus (CYSDV) and the potyvirus watermelon mosaic virus (WMV), transmitted by whiteflies and aphids, respectively (Desbiez et al. 2011; Navas-Castillo et al. 2014). Currently, CYSDV can be found throughout many tropical and subtropical areas where cucurbits are cultivated (Wintermantel et al. 2017). It has a bipartite, singlestrand, plus-sense RNA genome. As with other criniviruses, CYSDV is restricted to the phloem of the susceptible host, being transmitted by whiteflies such as Bemisia tabaci Gennadius in a semipersistent manner (Célix et al. 1996; Navas-Castillo et al. 2014). WMV (formerly also known as WMV2) has a worldwide distribution, predominantly in temperate regions, and has a large host range, being able to infect more than 170 plant species (Desbiez and Lecoq 2004). Similar to other potyviruses, WMV posses a positive-sense, single-stranded RNA genome that is translated into a polyprotein and subsequently processed by viral-encoded proteinases into functional products (Valli et al. 2015). Infection occurs in most plant tissues, and its transmission is mediated by different aphids, including Myzus persicae Sulzer, in a nonpersistent manner (Díaz-Pendón et al. 2005).

The objective of our study was to evaluate mixed infections of CYSDV and WMV in melon, in particular to determine whether the presence of both viruses could influence their transmission by vectors. To answer this question, we first compared the viral load of each virus in either single- or mixed-infected plants, following their accumulation during a period of 60 days, and complemented these measurements with observations of symptoms. Then, transmission experiments were performed in laboratory conditions to evaluate the influence of different plants (single- or mixedinfected) as virus sources. Furthermore, crinivirus transmission was also analyzed in field conditions. Regarding the transmission of WMV, the acquisition from single- or mixed-infected plants was compared using the electrical penetration graph (EPG) technique to measure the number and duration of the different phases and subphases involved. These latter two approaches were chosen to account for differences in transmission mechanisms (i.e., nonpersistent for WMV and semipersistent for CYSDV) (Bragard et al. 2013).

\section{MATERIALS ANDS METHODS}

Plants, insects, and viruses. Seed of the virus-susceptible melon cultivar Piel de sapo PS T111, provided by Semillas Fitó (Spain), were germinated after a 5-min treatment with the fungicide Captan in aqueous solution ( $3 \mathrm{~g} /$ liter). Plants were grown in incubators at 22 to $25^{\circ} \mathrm{C}$ with cycles of $16 \mathrm{~h}$ of light and $8 \mathrm{~h}$ of darkness.

A clonal population of the aphid $M$. persicae, designated MP89 and originally from the ICA-CSIC (Madrid, Spain), was maintained on tobacco plants (Nicotiana tabacum 'Xanthi'). This aphid species was shown to be particularly efficient in transmitting WMV (Díaz-Pendón et al. 2005). A colony of B. tabaci biotype MEAM1 (formerly biotype B) was provided by Dr. R. Gabarra
(IRTA-Cabrils, Barcelona, Spain), and was raised on tomato plants (Solanum lycopersicum 'Micro-Tom'). Plants supporting insects for laboratory experiments were kept in separate growth chambers at 23 to $25^{\circ} \mathrm{C}$ with cycles of $16 \mathrm{~h}$ of light and $8 \mathrm{~h}$ of darkness. For field experiments with whiteflies, individuals from a colony of B. tabaci biotype MED (formerly Q) were used (Rodríguez-López et al. 2012).

A Spanish isolate of the crinivirus CYSDV, designated CYSDVAlLM, was kindly provided by Dr. M. L. Gómez-Guillamón (IHSM "La Mayora", Málaga, Spain), and was maintained through periodical whitefly transmission on susceptible host plants.

The initial infection of WMV was achieved using an infectious full-length clone kindly provided by Dr. C. Desbiez (INRA-PACA, Avignon, France) following previously described procedures (Desbiez et al. 2011), and the virus was later propagated through aphid transmission.

CYSDV and WMV transmission experiments. Both CYSDV and WMV isolates were transmitted to melon plants using their natural vectors. Experimental conditions for CYSDV transmission were set after preliminary experiments testing temperature and the number of viruliferous whiteflies, with acquisition and inoculation access periods of $48 \mathrm{~h}$ each at a temperature of $25^{\circ} \mathrm{C}$ and a density of 20 whiteflies per plant. A controlled-vacuum hand trap and clamp cages were used for handling insects during transmission to individual plants. In experiments with a large number of test plants, sufficient viruliferous whiteflies to reach the chosen density were released inside insect-proof cages containing the plants to be inoculated.

The transmission of WMV by aphids was performed essentially as described previously for other potyviruses (Ruiz-Ferrer et al. 2005). Briefly, aphids were fasted for $3 \mathrm{~h}$ and then allowed to acquire and inoculate the virus during periods of 10 to $30 \mathrm{~min}$ in each case, being transferred manually from the source to the receptor plant with the help of a paintbrush, until 10 viruliferous aphids were placed on each individual test plant.

To account for the differences in inoculation periods, day 0 was considered after 2 days of infestation with viruliferous whiteflies or after 30 min with viruliferous aphids. In mixed-infected plants, CYSDV was first inoculated, then the whiteflies were removed, and aphids were allowed to inoculate WMV.

All vectors were killed with Confidor insecticide (imidacloprid $0.08 \%$; Bayer), and the plants were maintained to determine transmission rates by the presence of visual symptoms for WMV or through molecular diagnostic for CYSDV (see below). Single- and mixed-infected plants were always maintained side by side in the same growing conditions, and the results were analyzed separately for each one of the transmission experiments and also for the pooled data.

The CYSDV field transmission experiments were performed inside insect-proof walk-in net structures ( 5 by 5 by $2 \mathrm{~m}$ ) within a tunnel nethouse and in natural temperature and light conditions (Supplementary Fig. S1) (Rodríguez-López et al. 2012). Three plants infected with CYSDV or coinfected with CYSDV+WMV were used as inoculum source, surrounded by receptor plants $(n=20)$, either uninfected or previously infected with WMV, distributed in a circle of approximately $2 \mathrm{~m}$ in diameter. Approximately 800 nonviruliferous whiteflies were released in the center of the source plants, leading to a vector density of 40 whiteflies/plant. After 4 days, the receptor plants were treated with insecticide and transferred to a greenhouse for up to 30 days, using tissue print to determine the presence of CYSDV. Field experiments were performed in two consecutive years, using three independent net structures for each combination of source (CYSDV or CYSDV+WMV) and receptor (uninfected or WMV) plants (nochoice experiments; total $=12$ net structures). In free-choice experiments, 10 uninfected plants and $10 \mathrm{WMV-infected} \mathrm{plants}$ were distributed in alternating positions (three net structures for each type of source plant). 
Sampling, RNA extraction, and detection of viruses. Sampling of representative tissues was standardized to account for growth differences between uninfected, single, and double virusinfected plants. Two leaf discs ( $1 \mathrm{~cm}$ in diameter, pooled) were taken from the second to the latest fully expanded leaf at each sampling time point, regardless of size and position within the plant. Samples were immediately frozen in liquid nitrogen and ground in a TissueLyser (Qiagen). Total RNA was extracted using TRIzol reagent (Invitrogen) according to the manufacturer's instructions, including an additional ethanol precipitation to improve purity. Quality and concentration were estimated in a NanoDrop ND-8000 spectrophotometer.

The High-Capacity cDNA Reverse Transcription kit (Applied Biosystems) was used to generate cDNA from $1 \mu \mathrm{g}$ of total RNA, following the manufacturer's protocol. The cDNAs served as templates for amplification of viral sequences by PCR using TaKaRa ExTaq commercial kits. The number of cycles and conditions for amplification (temperature and extension time) were optimized for each combination of primers. Virus-specific oligos (Supplementary Table S1) were used to amplify an 813-nucleotide (nt) fragment in the coat protein region of WMV and a 563-nt fragment near the $3^{\prime}$ end of the genomic RNA2 of CYSDV (Marco et al. 2003). DNA fragments were analyzed by electrophoresis on agarose gels.

Quantification of viral load by reverse-transcription quantitative PCR. Virus quantification was performed with cDNAs generated from $1 \mu \mathrm{g}$ of total RNAs that were previously treated with DNase (ThermoScientific) by reverse-transcription quantitative PCR (RT-qPCR) and comparison with standard curves representing known dilutions of in vitro transcripts.

To generate virus transcripts, specific oligos were designed to amplify and clone fragments of approximately $1.5 \mathrm{~kb}$ located near the 5 ' ends of viral genomic RNA in each case (Supplementary Table S1). The plasmid pGEMT-Easy (Promega Corp.) was used to clone fragments deriving from the 5' ends of RNA 1 and RNA 2 of CYSDV, generating constructs RNA1ORF1CYSDV and RNA2Hsp70hCYSDV with the viral sequences under the control of $\mathrm{T} 7$ promoter to allow in vitro transcription with genome orientation (+ sense). For WMV, the complete P1 coding region was cloned into pENTR/DTOPO, and transferred by Gateway recombination to the vector pDEST 14 (Invitrogen) under the control of T7 promoter in genome orientation (+ sense). Constructs were verified by restriction analysis and sequencing. Transcripts were obtained with linearized plasmids as templates using the MEGAscript T7 kit (Ambion), quantified, and used as standards in RT-qPCR.

Two pairs of specific oligos were designed (https://www. genscript.com/tools/real-time-pcr-taqman-primer-design-tool) to amplify fragments ranging from 80 to $150 \mathrm{bp}$ for each viral RNA (Supplementary Table S1), and those resulting in better linear regression with the reference were selected in each case. SYBRGreen (Roche) was used to detect PCR products in a Light Cycler 480 (Roche) using $50 \mathrm{ng}$ of cDNA as template in the PCR.

Screening of CYSDV infected plants by tissue print and molecular hybridization. The presence of CYSDV before the onset of symptoms was determined by tissue printing and hybridization with a virus-specific probe (Más and Pallás 1995). Briefly, the plasmid pLM15/24 (Marco et al. 2003), kindly provided by Dr. M. Aranda (CEBAS-CSIC, Murcia, Spain) and containing a fragment of 5,437 bp from the virus RNA1 under the control of the SP6 promoter, was linearized with the restriction enzyme $X b a I$, and in vitro transcription was carried out using the digoxigenin (DIG) NORTHERN kit (Roche), following the manufacturer's instructions, to obtain negative-sense transcripts labeled with digoxigenin. The transcripts were hydrolyzed to a shorter size using a carbonate buffer treatment, ethanol precipitated, and resuspended until use (Marco et al. 2003).

Cross-sections of petioles were printed by pressing on positively charged nylon membranes (Roche), and the nucleic acids fixed by crosslinking at $120 \mathrm{~mJ} / \mathrm{cm}^{2}$ (UVC500 crosslinker; Amersham Biosciences). The membrane was incubated with prehybridization solution $(20 \times \mathrm{SSC}[1 \times \mathrm{SSC}$ is $0.15 \mathrm{M} \mathrm{NaCl}$ plus $0.015 \mathrm{M}$ sodium citrate], $10 \%$ N-lauryl sarcosine, $50 \%$ formamide, $10 \%$ sodium dodecyl sulfate [SDS], and $2 \%$ commercial blocking agent from Roche) at $65^{\circ} \mathrm{C}$ for $3 \mathrm{~h}$, before adding the denatured probe (heated for $10 \mathrm{~min}$ at $65^{\circ} \mathrm{C}$ ) and incubated for 14 to $16 \mathrm{~h}$ at $65^{\circ} \mathrm{C}$. Processing included two 10 - min rinses ( $2 \times$ SSC and $0.1 \%$ SDS), two $15-\mathrm{min}$ rinses $(0.1 \times \mathrm{SSC}$ and $0.1 \% \mathrm{SDS}), 5 \mathrm{~min}$ in washing solution $(0.1 \mathrm{M}$ maleic acid, $0.15 \mathrm{M} \mathrm{NaCl}$ [pH7.6], and $0.3 \%$ Tween 20), $1 \mathrm{~h}$ of blocking ( $0.1 \mathrm{M}$ maleic acid, $0.15 \mathrm{M} \mathrm{NaCl}$ [pH 7.6], and $1 \%$ commercial blocking agent of Roche), $1 \mathrm{~h}$ of incubation with antiDIG antibody (Roche) at the recommended concentration, and two 15 -min rinses in washing solution. The signal was visualized in a ChemiDoc chemiluminescence equipment (Bio-Rad) using CDPStar substrate (Roche) in detection buffer (0.1 M Tris-HCl [pH 9.5] and $0.1 \mathrm{M} \mathrm{NaCl}$ ).

Monitoring of the feeding behavior of aphids by EPG. Feeding behavior of $M$. persicae on melon plants was analyzed by EPG (Tjallingii 1978). Activities up to $1 \mathrm{~h}$ were recorded from individual insects feeding on plants (i) not inoculated, (ii) infected with CYSDV, (iii) infected with WMV, or (iv) infected with CYSDV+WMV. Adult apterous aphids were connected to a gold wire ( $3 \mathrm{~cm}$ long, $20 \mu \mathrm{m}$ in diameter) with a drop of silver conductive paint (Pelco Colloidal Silver number 16034; Ted Pella Inc.) on the dorsum. The wire was glued to a copper nail and connected to an EPG probe following standard procedures (Carmo-Sousa et al. 2014). Each wired insect was placed on the leaf of a plant, with the circuit closed through the plant substrate. Four plants were tested in parallel using a four-channel device (Giga-4; EPG Systems), and 20 to 30 replicates were recorded. EPG data acquisition was carried out using the Stylet+ software (EPG-Systems), to identify EPG waveforms described for aphids (Tjallingii 1988) corresponding to nonprobing, intercellular apoplastic stylet pathway, and intracellular stylet puncture. Other EPG waveforms occurring during the 1-h recording time were not evaluated.

Statistical analysis. For viral load measurements, statistical analysis of paired data were performed for each time point using a $t$ test when normality and homoscedasticity was confirmed and Mann-Whitney tests for other cases. The dynamics of virus accumulation were also analyzed separately for each virus (CYSDV or WMV) using two-way analysis of variance (ANOVA) with factors (i) time and and (ii) single or mixed infections, and the $\log _{2}$ of the viral load as response variable. This ANOVA could require a larger sample size because, as stated above, viral load was nonnormally distributed at some time points.

For the nonchoice field experiments, the comparison of transmission rates was performed applying $\chi^{2}$ or Fisher's exact test, in case of unequally distributed data, to the pooled values for each CYSDV source, either single- or mixed-infected plants. For the free-choice data, linear models were used to try to explain transmission as a function of three variables: source (single or mixed infected), individual net structure, and infection status (uninfected or preinfected with WMV). Also, multifactorial models were tested to predict the outcome as a function of a combination of the independent variables (considered as mutually independent, without interaction terms), and a model incorporating an interaction term between source and preinfection.

Behavioral variables were processed using a previously described MS Excel Workbook (Sarria et al. 2009). EPG variables (mean \pm standard error) were calculated (Backus et al. 2007) to determine proportion of individuals that produced a specific waveform type, number of wave-form events per insect, total waveform duration (in minutes) per insect, and total waveform duration (in minutes) per event. Results were analyzed after transformation using $\ln (x+1)$, and Mann-Whitney $U$ tests were conducted because of the non-Gaussian distribution of the data. 


\section{RESULTS}

Mixed-infected plants accumulated more CYSDV and less WMV compared with single infections. Levels of CYSDV and WMV were compared between single- and mixed-infected plants during 60 days after virus inoculation. To mimic natural conditions, infected plants were obtained using viruliferous whiteflies for CYSDV and aphids for WMV. Samples were collected every 12 days to quantify viral loads. At all time points, the titer of CYSDV was higher in mixed-infected compared with single-infected plants, with the major peak of accumulation occurring at 24 days postinoculation (dpi) during mixed infections (Fig. 1). On the other hand, WMV titers were lower in mixed-infected plants than for single infections for most of the analyzed time points, and the statistical comparisons found significance at all time points except at $12 \mathrm{dpi}$ (not shown). To assess whether viral load depended on mixed-infection status and its time dynamics, two-way ANOVA was applied for each virus. Analysis of CYSDV accumulation showed that it was affected by both time and infection status $(P<0.0001)$. In the case of WMV, the dependency of viral accumulation on time and infection status was also found significant, although to a lesser extent than in CYSDV $(P<0.0001$ and $P=0.005$, respectively). There were no statistically significant interactions between the effects of the two analyzed factors (time and infection status) on the accumulation levels for any of the viruses.

Mixed-infected plants at late time points recovered from the severe symptoms caused by WMV alone. Symptoms were observed during 60 days to compare single- and mixed-infected plants. In our experimental conditions, plants with individual infections showed the expected symptoms described for each virus: severe mosaic and puckering, with distortion of all leaves in WMVinfected plants; and mild leaf mottling, interveinal chlorosis, and yellowing, mainly visible in older leaves, in CYSDV-infected plants (Fig. 2A). Interestingly, symptoms in mixed-infected plants were very similar to those of a single infection by WMV during approximately the first half of the experiment (Fig. 2B) but, during the following 30 days, plants recovered and moderately regained growth and vigor, with a final appearance that was more similar to CYSDV single-infected plants (Fig. 2B and C). The same pattern of symptom development was observed and reproduced in all replicates of the experiments.

CYSDV transmission levels were similar at 24 dpi when comparing single- or mixed-infected source plants and in both controlled and field conditions. To determine whether the mixed infections affected the dissemination of the viruses by their natural vectors, we performed transmission experiments. First, we analyzed the transmission of CYSDV in controlled laboratory conditions, comparing whiteflies that acquired the virus from either single- or mixed-infected plants. Plants at 24 dpi were chosen as virus sources due to the highest CYSDV accumulation in mixedinfected plants (Fig. 1). Insects were allowed to acquire the virus during $48 \mathrm{~h}$ on infected plants; then, the viruliferous whiteflies were transferred to uninfected receptor plants for virus inoculation during $48 \mathrm{~h}$. The transmission rates were determined at $18 \mathrm{dpi}$, testing CYSDV presence by RT-PCR. Based on $\chi^{2}$ tests, no significant differences were found between transmission rates for each individual experiment when the whiteflies acquired the virus from mixed-infected
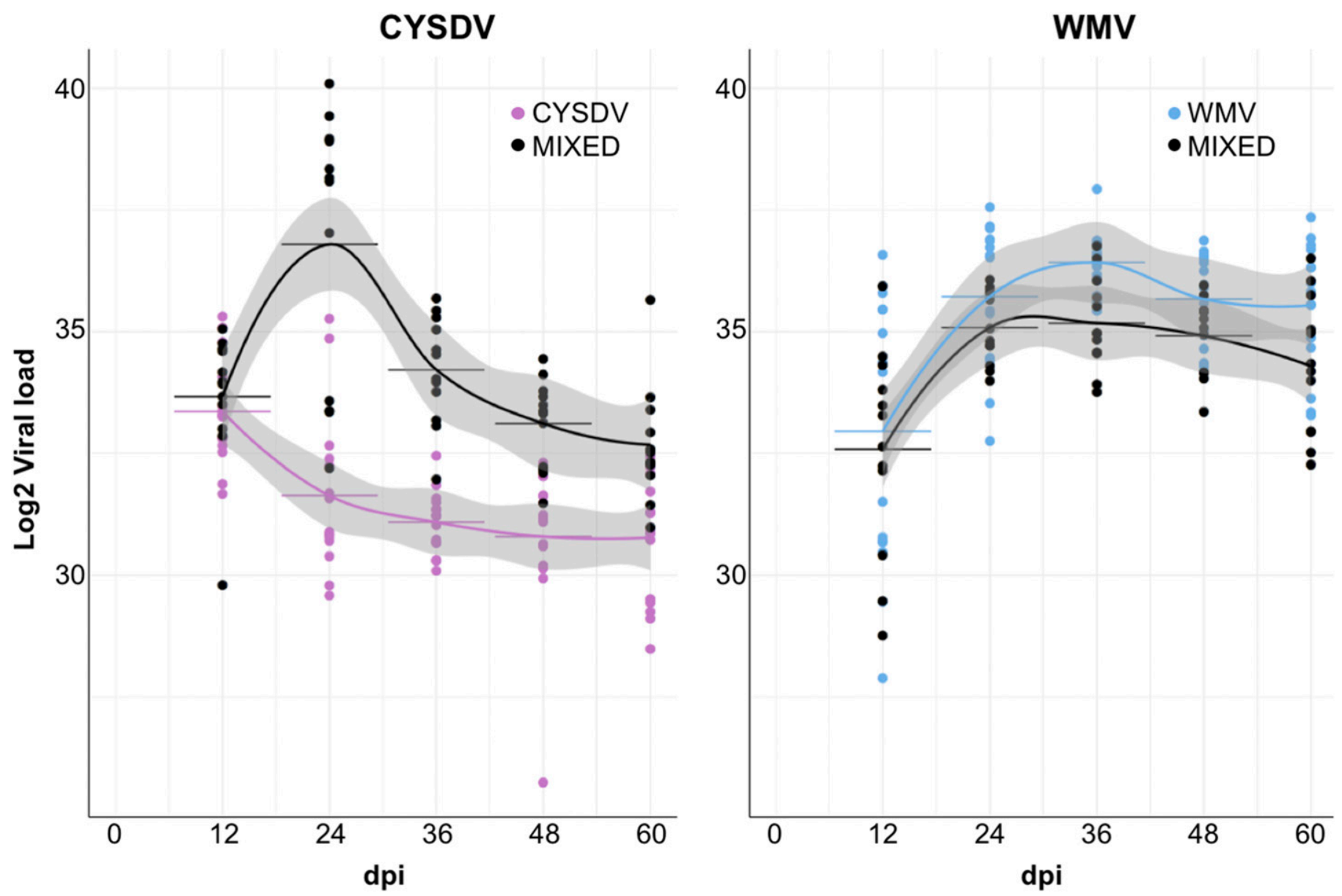

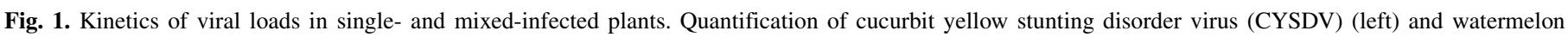

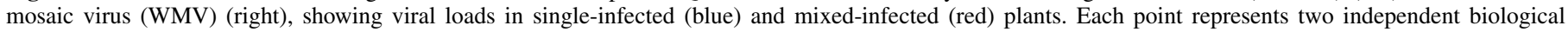

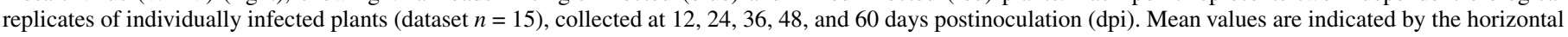

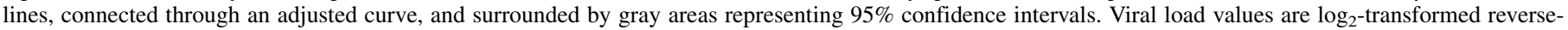
transcription quantitative PCR measurements of copy numbers per $0.1 \mathrm{~g}$ of sampled tissue. 
compared with single-infected plants (Fig. 3), although the pooled values reached a significantly higher transmission rate for CYSDV $(P<0.05)$, an unexpected result given the much lower viral load of CYSDV alone compared with CYSDV+WMV at the chosen time point for the acquisition.

Transmission experiments were also performed in field conditions during two consecutive years to determine whether the transmission rates of CYSDV were influenced by either the source plants (single or mixed infected at $24 \mathrm{dpi}$ ) or the receptor plants (uninfected or WMV-infected). Results (Figs. 4 and 5; Supplementary Tables S2 and S3) showed larger differences in transmission rates depending on the year; thus, the comparisons were done separately. Images of the experimental setup and the complete set of values are provided as supporting information (Supplementary Fig. S1; Supplementary Tables S2 and S3).

In the first experiment, transmission rates were almost identical when the viral source plants were either single- or mixed-infected plants, suggesting that the acquisition of CYSDV was not altered by the presence of WMV in mixed infections (Fig. 4). Although transmission rates were higher to WMV-infected than to uninfected receptor plants from the two kinds of inoculum sources, the difference was not statistically significant in the case of the singleinfected source $\left(\chi^{2}=0.4, \mathrm{df}=1, P=0.527\right)$ whereas, in the case of the mixed-infected source plants, the pooled values of the three independent net structures reached a significant difference for higher transmission to preinfected plants (Fisher's exact test, $P=$ 0.0157).

The experimental design in the second year was modified to allow comparison of inoculation choices to either uninfected or WMV-infected plants alternated in every net structure. The results (Fig. 5A and B; Supplementary Supplementary Table S3) confirmed the absence of significant differences between the transmission rates to WMV-infected plants compared with uninfected plants for the pooled values in both the single-infected
A
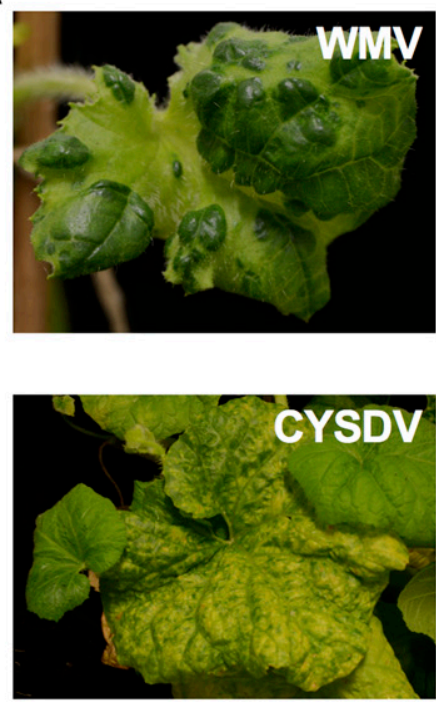

C
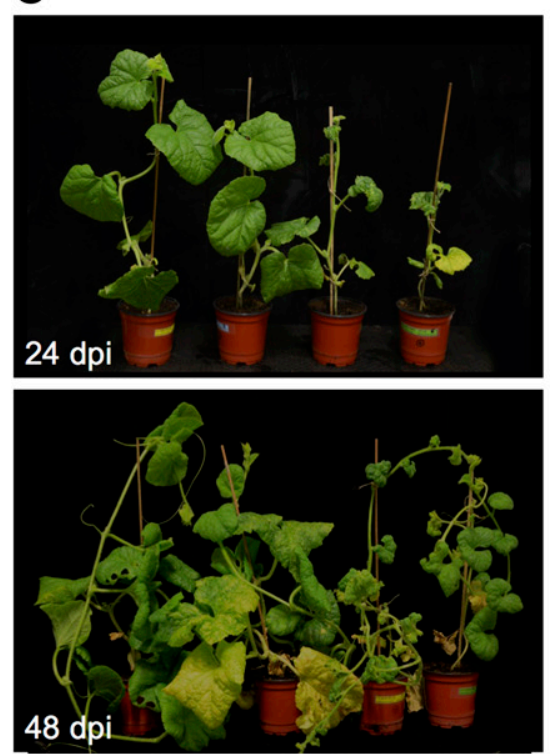

B
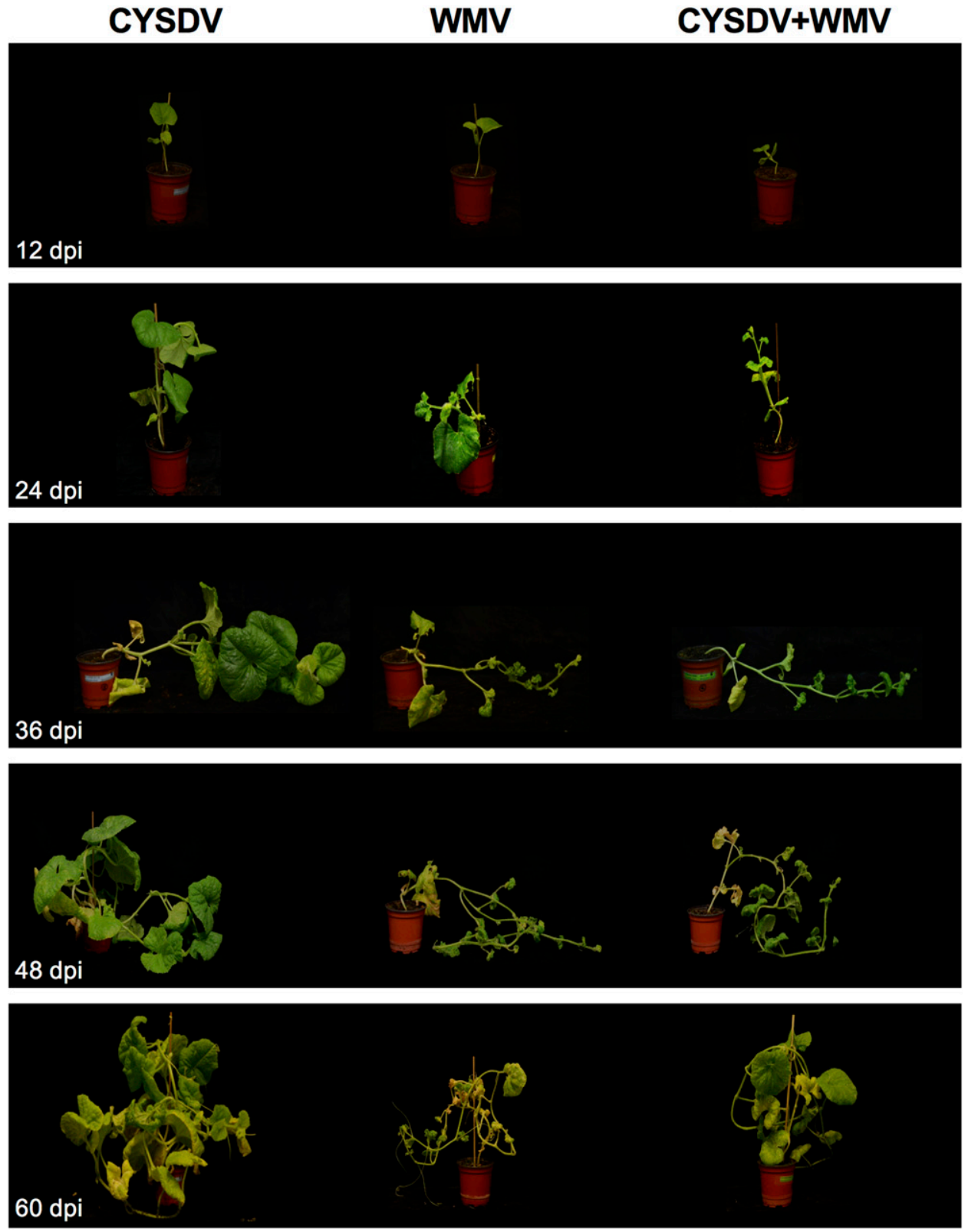

Fig. 2. Symptomatology of infected plants. A, Details of leaves with symptoms caused by single infection with watermelon mosaic virus (WMV) (upper panel) or cucurbit yellow stunting disorder virus (CYSDV) (lower panel). B, Representative single- and mixed-infected plants photographed at the indicated time points. C, Side-by-side representative plants of the four categories (from left to right: noninfected, CYSDV, WMV, and CYSDV+WMV) photographed at 24 and 48 days postinoculation (dpi) corresponding to the stages used as virus sources during vector-transmission experiments. 
source $\left(\chi^{2}=1.73, \mathrm{df}=1, P=0.188\right)$ and the mixed-infected source $\left(\chi^{2}=1.66\right.$, df $\left.=1, P=0.196\right)$. However, the slight preference of viruliferous whiteflies to transmit the crinivirus to plants previously infected with the potyvirus was again observed in two of the three replicates, regardless of the source of virus acquisition (Fig. 5). In order to evaluate this putative preference for preinfected plants, linear models were tested for the dependence of transmission as a function of different variables. Although the variable preinfection status explained $23.1 \%$ of the variation in transmission, this relationship was not statistically significant $(P=0.114)$. Linear regression with other variables such as source or net structure also resulted in no statistical significance, and the same was also true for multifactorial models, including two or three of the variables with or without interaction terms. Therefore, further data will be required to confirm the potential preinfection effect.

Reduced WMV levels in mixed-infected plants do not result in reduced transmission of WMV by aphids at 24 dpi. To test whether the mixed infections affected transmission of WMV, a different methodology was adopted, taking into consideration the differences of the nonpersistent and semipersistent transmission processes. Apterous aphids were fed on a leaf of a single- or mixed-infected melon plant to acquire the virus, and subsequently manually transferred to test plants for virus inoculation. After insecticide treatment, the plants were observed until appearance of WMV symptoms. Despite the lower viral titers in the mixed-infected plants at 24 dpi (Fig. 1; Fig. 6, upper panel), the transmission rates when the insects acquired the virus from a mixed-infected plant compared with a single-infected one were not significantly different in two of the three individual experiments or for the pooled values (Fig. 6).

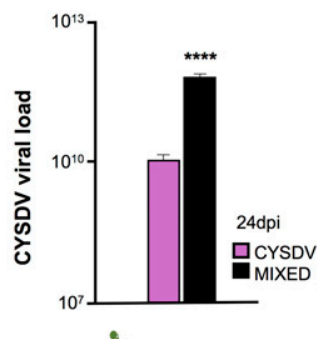

\begin{tabular}{|c|c|c|c|c|c|}
\hline Inoculum source & & CYSDV & CYSDV+WMV & Chi-square, df & $P$ value \\
\hline \multirow{3}{*}{$\begin{array}{l}\text { Transmission } \\
\text { rates }\end{array}$} & Exp.1 & $27 / 40$ & $19 / 40$ & $3.27,1$ & 0.07 \\
\hline & Exp. 2 & $15 / 39$ & $14 / 40$ & $0.10,1$ & 0.75 \\
\hline & Exp. 3 & $30 / 40$ & $22 / 40$ & $3.52,1$ & 0.06 \\
\hline Total & & $72 / 119$ & $55 / 120$ & $5.16,1$ & 0.02 \\
\hline $\begin{array}{c}\text { Average } \\
\text { CYSDV } \\
\text { transmission }\end{array}$ & 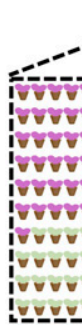 & 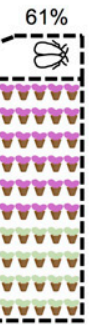 & 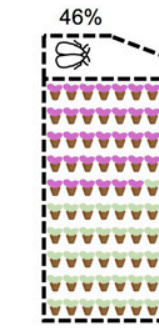 & 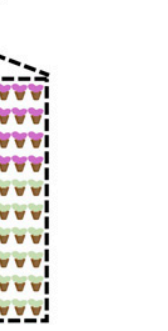 & \\
\hline
\end{tabular}

Fig. 3. Cucurbit yellow stunting disorder virus (CYSDV) transmission in controlled conditions at 24 days postinoculation (dpi). Pooled values of virus accumulation are plotted on the upper panel (compared by Mann-Whitney $U$ test) above the tabulated results of the three replicates of transmission, with number of infected plants/number of plants tested for each independent experiment, followed by the values of two-tailed $\chi^{2}$ tests $(\mathrm{df}=1)$. Transmission rates are shown graphically (shaded for CYSDV-infected versus no shading for uninfected test plants. Viral load values are reverse-transcription quantitative PCR measurements of copy numbers per $0.1 \mathrm{~g}$ of sampled tissue.
Aphid feeding behavior was altered on mixed-infected plants. The feeding behavior of aphids was monitored using EPG to determine whether it was influenced by single or mixed infections in the source plants. We fed wired aphids on (i) uninfected control plants, (ii) single-infected plants with CYSDV, (iii) singleinfected plants with WMV, and (iv) mixed-infected plants with both CYSDV and WMV. The results indicated that the presence of CYSDV alone did not have any major effect on the behavior of aphid vectors compared with control uninfected plants, with the most relevant parameters showing similar values or minor changes not associated with transmission-relevant activities (Supplementary Table S4). However, we observed that aphids spent more time without probing on plants infected with WMV compared with mixed-infected plants (Table 1). Also, a longer duration of the intracellular punctures (detectable as potential drops [Pds]) was observed on plants infected with CYSDV+WMV, with differences after grouping the data by both insect and event (Supplementary Table S5). The statistical analysis of the duration of each of the subphases of the Pds confirmed the existence of significant differences in the case of subphase II-3 (Fig. 7A), which was previously associated with acquisition of nonpersistently transmitted viruses (Collar et al. 1997). The duration of subphase II-3 of the Pds (Fig. 7B; complete data set in Supplementary Table S5) and the number of pulses (Fig. 7C) were significantly higher in plants infected with CYSDV+WMV.

At later time points, mixed-infected plants used as source produced similar rates of aphid transmission of WMV but higher rates of whitefly transmission of CYSDV. The observed recovery of plants with mixed infections of WMV+CYSDV at late time points (Fig. 2) prompted us to perform additional measurements of vector transmission rates. For these experiments, five groups of 10 test plants each were considered as
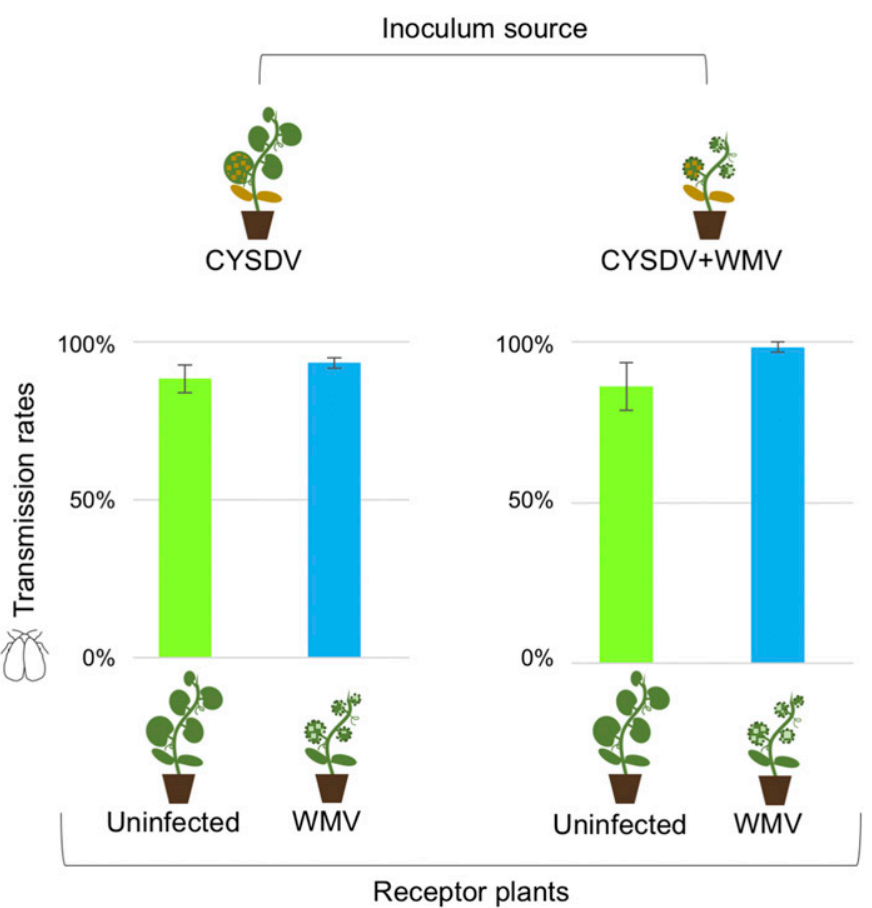

Fig. 4. Transmission of cucurbit yellow stunting disorder virus (CYSDV) in field conditions. Average of transmission rates in three individual net structures, with 20 test plants each, either uninfected or previously infected by watermelon mosaic virus (WMV), and surrounding single-infected CYSDV plants (left panel) or mixed-infected CYSDV+WMV plants (right panel) as sources of inoculum. No significant difference was found for pooled values in the case of CYSDV source plants $\left(\chi^{2}=0.4\right.$, df $\left.=1, P=0.527\right)$, whereas significance was reached for the pooled values in the CYSDV+WMV source case (Fisher's exact test, $P=0.0157$ ). 
biological replicates for each one of the four cases: whitefly transmission of CYSDV and aphid-transmission of WMV, using as virus sources for acquisition either single-infected (CYSDV or WMV, respectively) or mixed-infected (CYSDV+WMV) plants at 52 dpi. Results are shown in Figure 8.

The transmission of CYSDV was much higher (98.0\%) from mixed-infected plants compared with the single-infected source $(62.0 \%)$, with significant differences $\left(\chi^{2}, \mathrm{df}=1, P<0.0001\right)$, strongly contrasting with the results obtained at 24 dpi (Fig. 3). Comparing the source plants at these two time points, the recovered mixed-infected plants served as a better virus source for whitefly

A

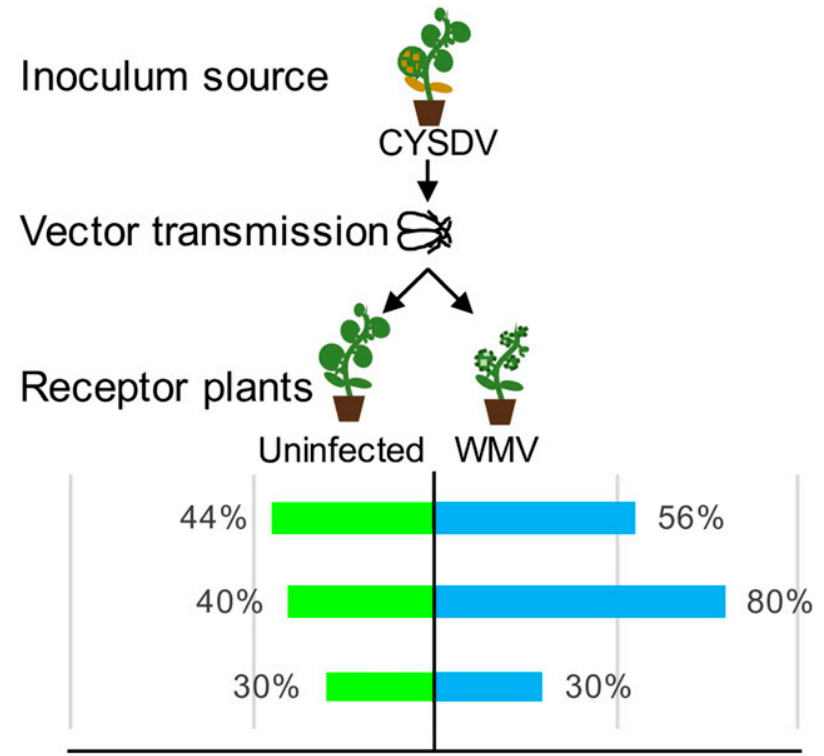

Transmission rates

B

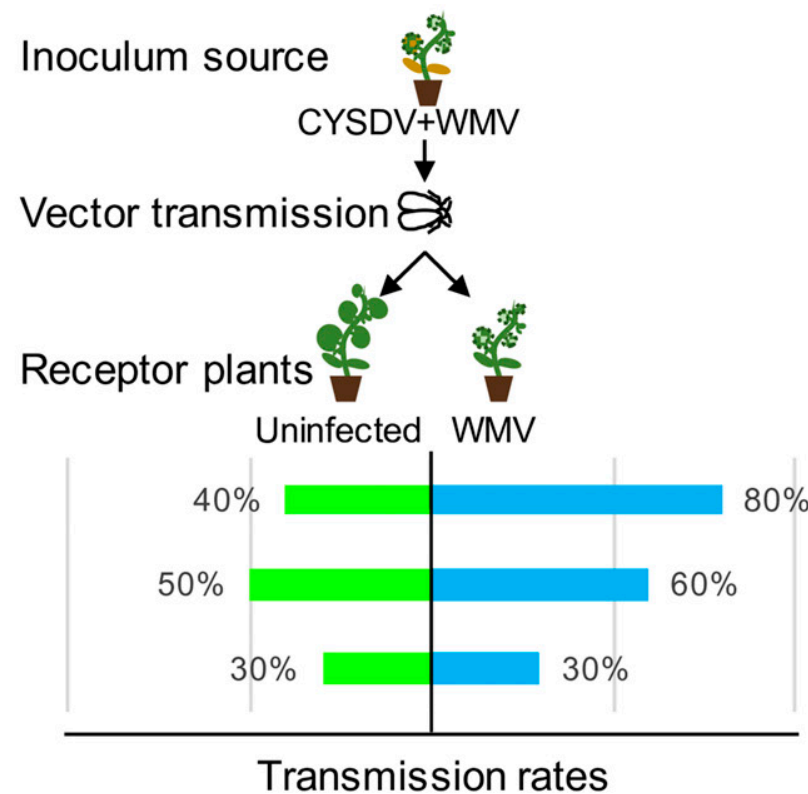

Fig. 5. Free-choice transmission of cucurbit yellow stunting disorder virus (CYSDV) in field conditions. A, Graphical representation of comparative transmission of CYSDV to plants, 10 uninfected and 10 previously infected with watermelon mosaic virus (WMV) arranged in alternating positions, using single-infected CYSDV plants as source of inoculum; results for each individual net structure are represented separately. B, Similar experiment as in A, with mixed-infected CYSDV+WMV plants as inoculum source. transmission. On the other hand, WMV transmission rates were 74.5 and $67.3 \%$ from single- and mixed-infected sources, respectively, not showing significant differences $\left(\chi^{2}\right.$, df $=1, P=$ 0.443 ) and reaching values in the same range as those found at 24 dpi (Fig. 6), despite the clear differences in WMV accumulation at late time points of infection between single- and mixed-infected plants.

\section{DISCUSSION}

Plants naturally infected by more than one virus are common in both natural and agricultural environments (Juarez et al. 2013; Peñaflor et al. 2016; Roossinck et al. 2010; Tugume et al. 2016; Zinga et al. 2013). However, few studies have addressed the ecological implications of such mixed viral infections (Elena et al. 2014). The interactions among hosts, pathogens, and vectors could result in an equilibrium with significant effects on each of the three players (Mauck 2016), as expected in any parasitic interaction (Lefèvre et al. 2009). Antecedents pointing to the importance of these relationships during mixed infections have been described. For instance, potentially relevant ecological repercussions of complex host-pathogens interactions have been found between unrelated pathogens such as bacteria and viruses (Shapiro et al. 2012, 2013). Concerning viruses, the recently reviewed ecological implications of host manipulation (Mauck et al. 2018) derive mainly from reports related to single infections, as in several available examples (Eigenbrode et al. 2002; Ingwell et al. 2012; Mauck et al. 2010; Stafford et al. 2011), although a recent study considered double infections caused by two persistently transmitted viruses (Chen et al. 2018). Repercussions of other combinations of

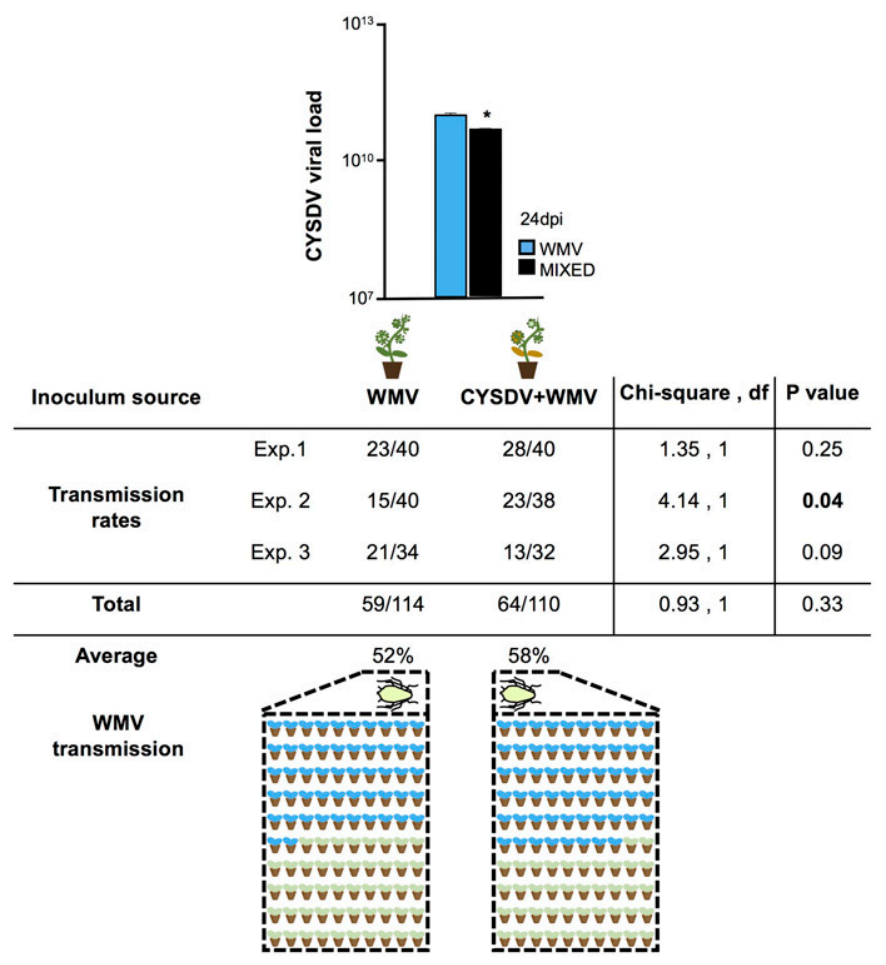

Fig. 6. Watermelon mosaic virus (WMV) transmission in controlled conditions at 24 days postinoculation (dpi). Pooled values of virus accumulation are plotted on the upper panel (compared using $t$ test) above the tabulated results for the three replicates of the experiment, with number of infected plants/ number of plants tested for each independent experiment, followed by the values of two-tailed $\chi^{2}$ tests $(\mathrm{df}=1)$. Transmission rates are shown graphically (shading for WMV-infected versus no shading for uninfected test plants). Viral load values are reverse-transcription quantitative PCR measurements of copy numbers per $0.1 \mathrm{~g}$ of sampled tissue. 
viral infections such as nonpersistently and semipersistently transmitted viruses are mostly unknown.

In the case of cucurbits, surveys revealed that mixed viral infections are quite common (Gil-Salas et al. 2012; Juarez et al. 2013; Sufrin-Ringwald and Lapidot 2011). We focused our work on melon plants infected by two viruses that generate important economic losses: WMV and CYSDV (Abrahamian and AbouJawdah 2014; Juarez et al. 2013). Mixed viral infections were established experimentally using aphids and whiteflies, and the viral load for each individual virus was determined during 60 dpi. Our results showed that CYSDV accumulated to higher titers in mixed-infected compared with single-infected plants at all time points, with a peak at $24 \mathrm{dpi}$, while the viral load of WMV was consistently lower in mixed-infected plants than in single infections. These results confirmed similar kinetics reported during mixed infections involving a potyvirus and other plant viruses,

A

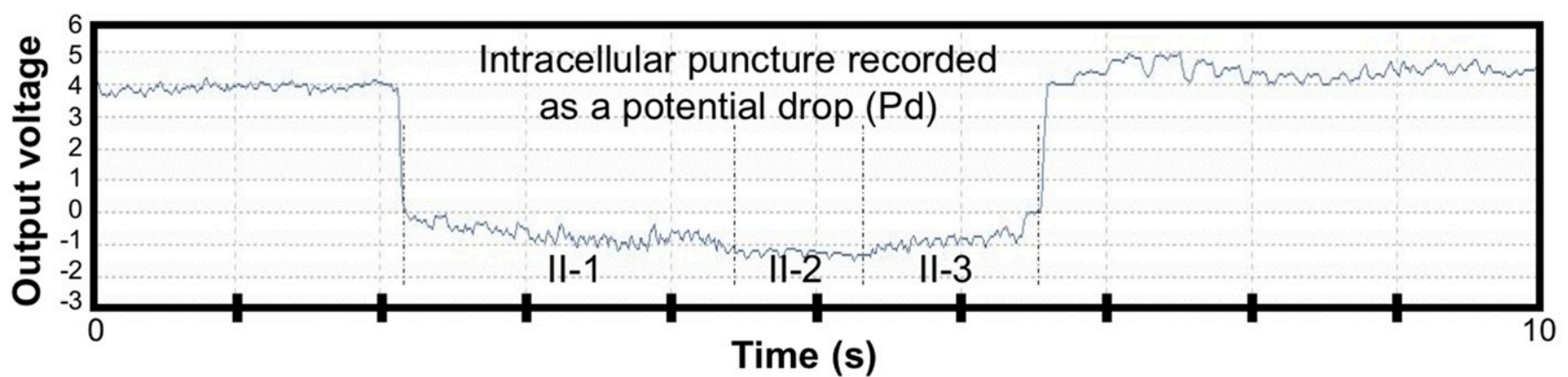

B
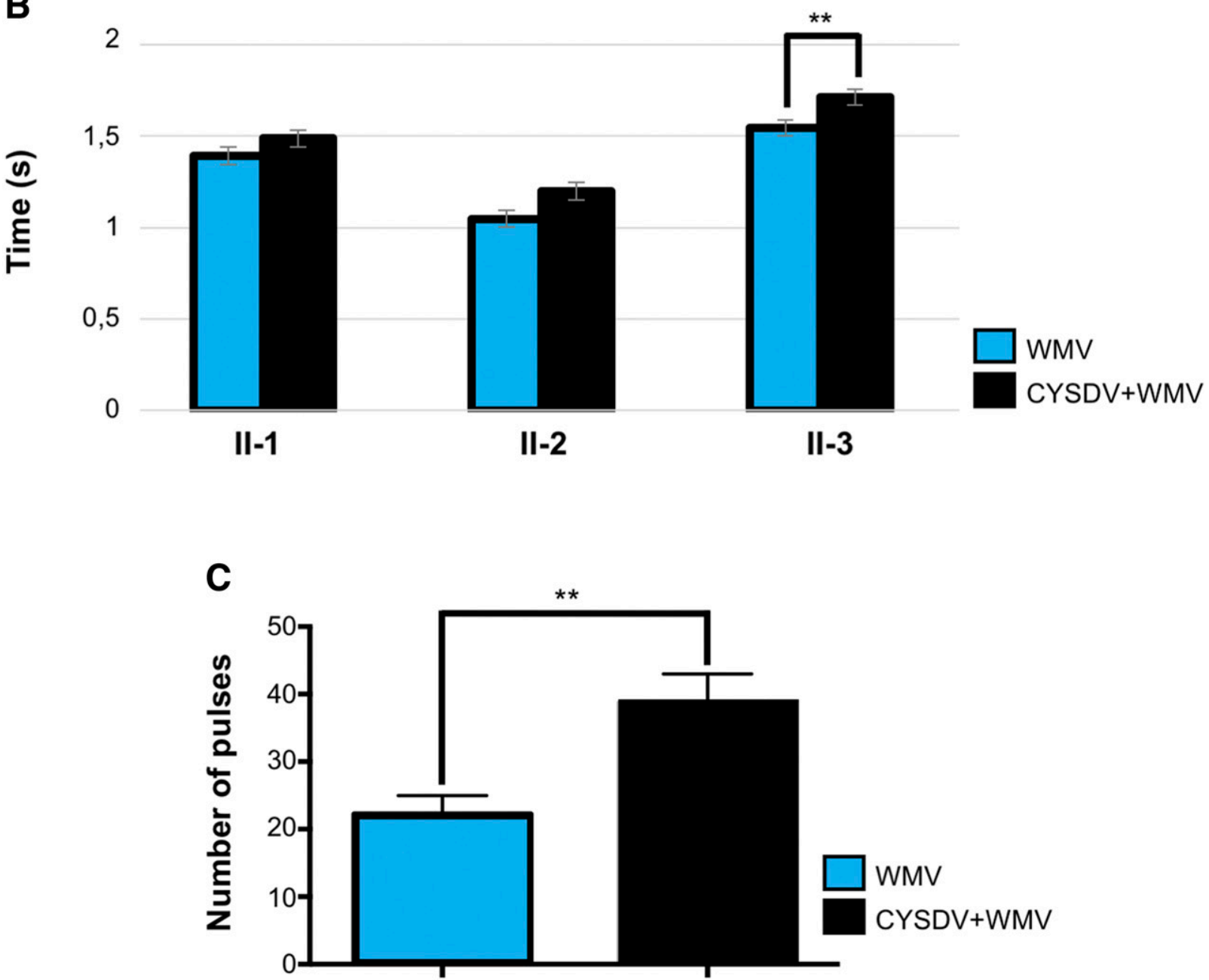

II-3

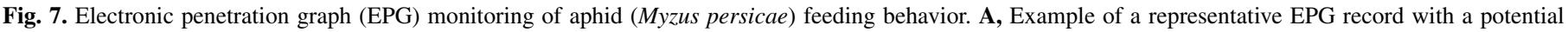

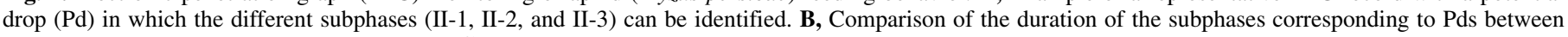

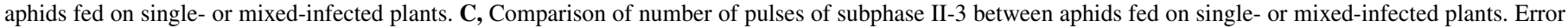
bars represent \pm 1 standard error of the mean. 
including criniviruses. The most common pattern revealed that, in mixed infections, the accumulation of the potyvirus tended to remain similar or lower compared with single infections, while accumulation increased for the nonpotyvirus partner (Murphy and Bowen 2006; Wang et al. 2009). This usual outcome might be due, at least partially, to attenuation of the host RNA silencing-related antiviral defense by the strong activity of the RNA-silencing suppressor helper-component protease (HC-Pro) present in most potyviruses (Valli et al. 2018). This hypothesis is also indirectly supported by the atypical case of the mixed infection between the

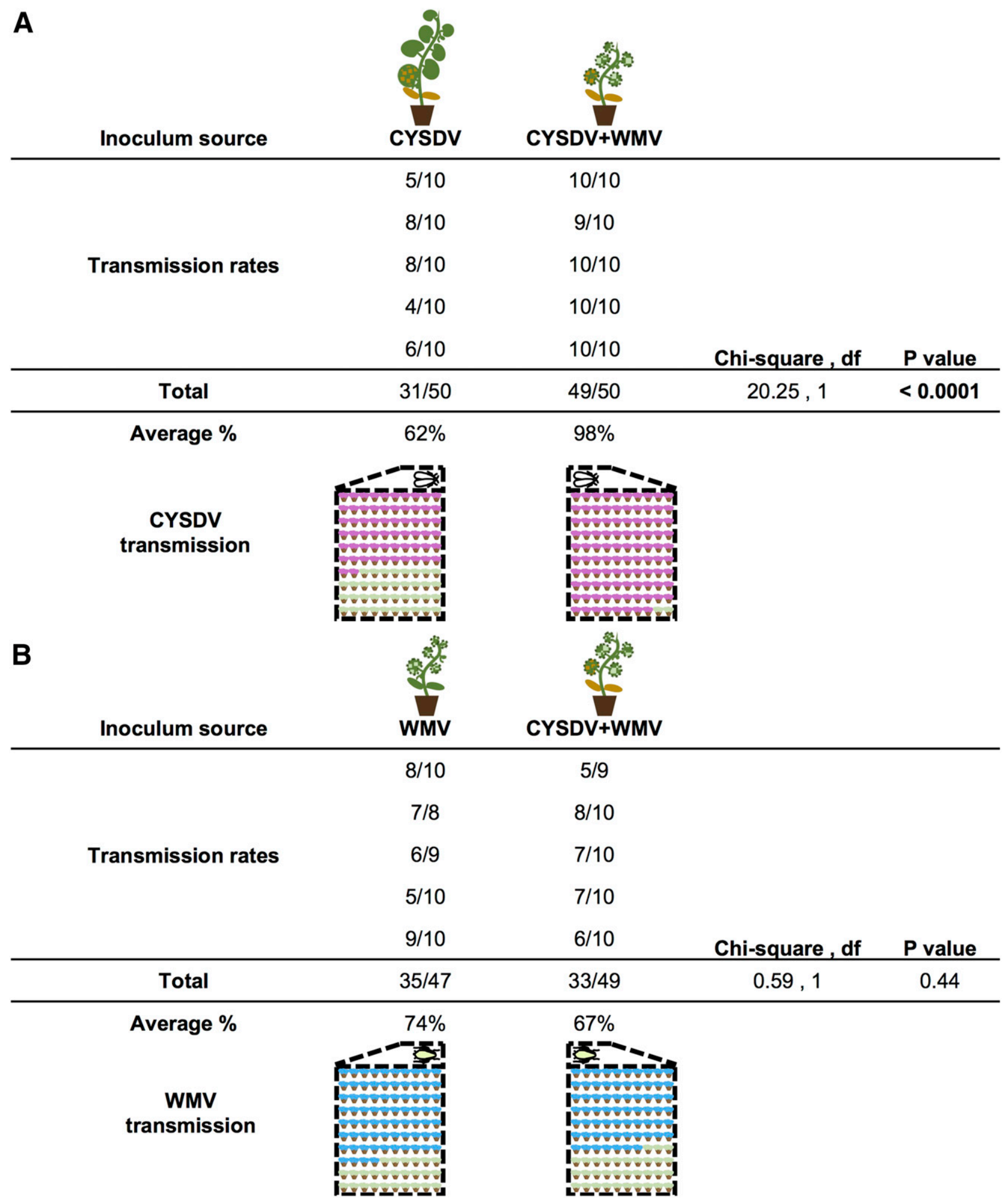

Fig. 8. Cucurbit yellow stunting disorder virus (CYSDV) and watermelon mosaic virus (WMV) transmission in controlled conditions at 52 days postinoculation. The transmission rate of A, CYSDV by whiteflies and $\mathbf{B}$, WMV by aphids is shown for five independent experiments using 10 plants each, with the number of infected plants/number of plants tested for each independent experiment, and the pooled total followed by the value of a two-tailed $\chi^{2}$ test $(\mathrm{df}=1)$. Transmission rates are depicted graphically using the same shading as in previous figures (shading for CYSDV-infected and WMV-infected, and no shading for uninfected test plants). 
potyvirus sweet potato feathery mottle virus (SPFMV) and the crinivirus sweet potato chlorotic stunt virus in sweet potato plants, in which the potyvirus does not generate a synergism in the usual direction, a fact that could be related to the almost complete lack of RNA silencing suppressor activity in the SPFMV HC-Pro (Mingot et al. 2016). In the case of a mixed infection of two potyviruses such as WMV and zucchini yellow mosaic virus (ZYMV) in squash (Cucurbita pepo), it was reported that ZYMV replicated at similar rates in single and mixed infections, whereas WMV accumulated to significantly lower levels in the presence of ZYMV, although it was still readily transmitted from mixed-infected plants (Salvaudon et al. 2013).

The virus-virus interaction during mixed infection is considered essential for the combined disease. Outcomes can be classified as antagonistic or synergistic, with synergisms being caused in many cases by combinations of unrelated viruses (Syller 2012). At the same time, the possible effects in the plant caused by mixed infections could range from beneficial to neutral or detrimental. CYSDV and WMV belong to very distinct viral groups, crinivirus and potyvirus, being transmitted by unrelated insects, semipersistently by whiteflies and nonpersistently by aphids, respectively. A superficial analysis of these differences can lead to the assumption that they might not share the same niches (such as host tissues being infected) and, thus, might not compete for vector transmission or host resources, which could lead to synergism rather than antagonism (DaPalma et al. 2010). In fact, this is roughly what we observed until around the midpoint of the kinetics of virus accumulation. Unexpectedly, the situation appeared to be reversed after a prolonged mixed-infection period, revealing a more complex interaction between the two viruses. The severity of symptoms caused by CYSDV infection have been directly correlated with the viral load in the plant (Eid et al. 2006; Marco et al. 2003) and, thus, the higher titers of CYSDV in our mixed-infected plants could be one of the factors leading to more pronounced disease symptoms during the initial stages of the double infection. However, we observed that mixed-infected plants began to recover gradually, starting around 36 to $48 \mathrm{dpi}$, and, by $60 \mathrm{dpi}$, symptoms were considerably less severe in mixed-infected plants than the ones infected only with WMV. Symptom recovery has been described in some viral infections as related to RNA-silencing mechanisms (Lim et al. 2011) but further studies will be needed to determine whether this is also the case for CYSDV+WMV.

When we analyzed the CYSDV transmission rates to healthy plants in laboratory conditions at $24 \mathrm{dpi}$, we found no significant differences when comparing single- or mixed-infected plants as virus sources, despite the higher titers in the latter. In fact, it was shown previously that accumulation of CYSDV associated with an increase of symptoms might negatively influence transmission, at least in noncucurbit hosts (Wintermantel et al. 2016). However, the situation was reversed at $52 \mathrm{dpi}$, with mixed-infected plants becoming a better source for virus transmission. It is not straightforward to explain these differences in transmission rates at 24 and $52 \mathrm{dpi}$, especially considering that the viral load was lower at the later time point (Fig. 1). One possible explanation for this observation might be that the severely deformed leaves of the mixed-infected plants at the early time point could cause steric difficulties for the whiteflies to reach the phloem and acquire the virus, whereas the larger and less-deformed leaves of CYSDV single-infected plants were more accessible for vectors. This circumstance might disappear later, after the recovery of the plants with WMV+CYSDV (Fig. 2), perhaps leading to a more comparable topology of leaves where the higher virus load would become the main determinant for transmission success. Such interactions have been described in certain conditions; for instance, when the presence of a satellite modifies transmissibility of the helper virus (Escriu et al. 2000). However, we cannot rule out other explanations. For example, in other combinations involving phloem-restricted viruses, coinfection with viruses not restricted to the vasculature can remove phloem limitations and make the virus more accessible for vectors, as in the case of potato leafroll virus and the potyvirus potato virus A (Savenkov and Valkonen 2001). Additional work will be needed to test these or other hypotheses.

When CYSDV transmission was tested in field conditions, similar rates were obtained when comparing single- or mixedinfected plants, suggesting that the acquisition process was not affected, regardless of the presence or absence of WMV in the source plants. However, we need to keep in mind that, in field conditions, reproducibility of the experiments is often compromised, as shown by variations between results of the 2 years, probably reflecting differences in vector activity caused by variable environmental conditions, most likely temperature. Despite this variability, in the first set of experiments, we observed slightly higher transmission rates toward WMV-preinfected plants compared with uninfected test plants (Fig. 4). This observation suggested that the dissemination of CYSDV might be biased toward plants previously infected by potyviruses. Indeed, a repeat of the field experiments allowing free choice to the viruliferous whiteflies during the inoculation period confirmed that the virus was again preferentially inoculated to WMV-preinfected plants compared with uninfected controls (Fig. 5A and B). In other words, the influence of the potyvirus presence in mixed infection could be operating not only in the acquisition and transmission of the unrelated crinivirus at late time points but also in the inoculation process to favor mixed infections. Such effects of vector attraction are more likely to be expected in semipersistently transmitted viruses whereas, for nonpersistently transmitted viruses such as WMV, effects on acquisition will be more relevant for the

TABLE 1. Selected electronic penetration graph (EPG) variables describing the feeding behavior of Myzus persicae on melon plants with single- or mixed-virus infections ${ }^{\mathrm{a}}$

\begin{tabular}{|c|c|c|c|c|c|c|c|}
\hline Variable, treatment & PPW & NWEI & $P$ & WDI & $P$ & WDE & $P$ \\
\hline \multicolumn{8}{|l|}{$\mathrm{Np}$} \\
\hline WMV & $30 / 30$ & $0.80 \pm 0.17(0.48-1.04)$ & 0.73 & $3.07 \pm 0.27(2.28-3.32)$ & 0.04 & $2.10 \pm 0.53(0.65-3.18)$ & 0.03 \\
\hline \multicolumn{8}{|c|}{$0.82 \pm 0.23(0.30-1.18)$} \\
\hline WMV & $30 / 30$ & $0.77 \pm 0.18(0.30-1.00)$ & 0.48 & $2.75 \pm 0.31(2.08-3.25)$ & 0.06 & $1.69 \pm 0.55(0.94-3.05)$ & 0.74 \\
\hline CYSDV+WMV & $28 / 28$ & $0.80 \pm 0.22(0.30-1.15)$ & & $2.91 \pm 0.27(2.36-3.26)$ & & $1.68 \pm 0.59(0.92-3.26)$ & \\
\hline \multicolumn{8}{|l|}{$\mathrm{Pd}$} \\
\hline WMV & $30 / 30$ & $1.14 \pm 0.26(0.60-1.59)$ & 0.12 & $1.75 \pm 0.25(1.11-2.13)$ & 0.02 & $0.70 \pm 0.08(0.52-1.12)$ & $<0.0001$ \\
\hline
\end{tabular}


transmission outcome. The explanation of this possible preference for WMV preinfected plants during inoculation of CYSDV by viruliferous whiteflies will require further experimentation but we can hypothesize that mechanisms such as a reduced expression of jasmonic acid-responsive genes, shown in potyvirus-infected plants (Westwood et al. 2014), could increase attraction to whiteflies. However, in order to generate more conclusive data, further observations will be needed, including data on frequencies and duration of vector visits to each kind of plant. Also, outside of vector preferences, alternative explanations might be based on other types of interactions such as a hypothetical effect of WMV preinfection in favoring the subsequent establishment of CYSDV.

The results of WMV transmission experiments showed mostly unaltered rates at both early and late time points regardless of the observed changes in viral load, with reduced virus accumulation in mixed-infected plants, although we must keep in mind that empirical support for the minimum titer of WMV necessary for acquisition is lacking. In fact, our own results with the crinivirus and whiteflies indicated a lack of correlation between viral titers and vector transmission efficiency and, consequently, the simplistic view that higher virus accumulation always results in better transmission should be reconsidered and analyzed case by case. Also, our experiments with WMV were performed with only one aphid species, and it is important to note that other putative vectors might not provide the same results, and the data should not be generalized.

The transmission process was further analyzed by EPG to quantify aspects of aphid feeding behavior. This technique has been used in a number of studies (Garzo et al. 2016; Moreno et al. 2012; van Munster et al. 2017) but, to our knowledge, this is the first case in which plants single or mixed infected with viruses were compared. The behavior of aphids was recorded when feeding on uninfected, CYSDV-infected, WMV-infected, or mixed-infected plants, and significant differences were found for transmissionrelevant parameters between WMV-single- and mixed-infected plants. Our results clearly showed that aphids, when feeding on mixed-infected plants, spent more time in the subphase correlated with acquisition of nonpersistent viruses (Collar et al. 1997), and also produced more pulses during intracellular stylet punctures (Pds). Interestingly, no differences in number and duration of $\mathrm{Pd}$ waveforms per insect were observed between uninfected plants and single-infected plants with either WMV or CYSDV alone, suggesting that the observed changes in aphid behavior on mixedinfected plants might be attributed to the simultaneous presence of both viruses. For the future, it remains to be determined whether these changes respond to differential attractiveness or nutritional conditions of plants, changes in the defense mechanisms of plants during mixed infections, or alterations in the anatomy of the leaves (texture, thickness, composition of cell contents, or others), and how these specific changes are caused by the simultaneous presence of the two viruses and not by each one individually. It is relevant to recall that the transmission mechanisms are different for criniviruses and potyviruses, which can have implications for the manipulative strategies of vector-borne pathogens, as suggested recently (Mauck et al. 2018). In fact, manipulative strategies by vectors have been reported only for a few cases of mixed infections (Bourdin and Lecoq 1991; Froissart et al. 2002; Perry and Francki 1992; Rochow 1972) but the present work, addressing the transmissibility from coinfections of a potyvirus and a crinivirus, suggests that the possible effects of mixed infections on vector transmission might be more general than previously thought; although, again, we need to be cautious because our results were obtained with a particular pathosystem and other combinations of viruses and vector species might provide different outcomes.

To summarize, we observed that titers of CYSDV remained higher in mixed-infected plants, thereby increasing the chances of being transmitted, while the plants were also able to support more whitefly vectors after recovering from the initially more severe symptoms. Indeed, our experiment at 52 dpi showed a clear increase of the transmission rate for CYSDV when acquired from mixedinfected plants. Regarding the other virus partner, transmission experiments indicate that WMV could also benefit from its presence in mixed infections, even if the viral titers were lower compared with single-infected plants at most time points, because, in this case, the extension of subphase II-3 (related to virus acquisition) may compensate for lower titers. In other words, during mixed infections, CYSDV might enhance its accumulation in plants less severely affected (and, thus, prone to survive longer and in better condition) and, consequently, its chances of dissemination; and, at the same time, the less abundant WMV might be maintaining the same transmission rates thanks to alterations in the feeding behavior of its vector. From an ecological point of view, mixed-infected plants would confer adaptive advantages to both viruses for their respective dissemination. The implications of multiple infections for the evolution of pathogens (Tollenaere et al. 2016) are being explored in some virus pathosystems (Ali and Roossinck 2017), and our results suggest that vectors might be key elements in the outcome. Although additional work will be needed to elucidate all of the mechanisms operating during mixed infections, we believe that our results might be useful to explore how the interactions and their dynamics can determine available strategies to control viral diseases in crops.

\section{ACKNOWLEDGMENTS}

We thank S. Sánchez Campos and G. Lozano for their contribution during field experiments; M. Bernardo, V. González, and members of the CRAG "I love data club" for assistance with statistical analysis; and S. Elena and M. Roossinck for their comments and suggestions.

\section{LITERATURE CITED}

Abrahamian, P. E., and Abou-Jawdah, Y. 2014. Whitefly-transmitted criniviruses of cucurbits: Current status and future prospects. VirusDisease 25: 26-38.

Alexander, H. M., Mauck, K. E., Whitfield, A. E., Garrett, K. A., and Malmstrom, C. M. 2014. Plant-virus interactions and the agro-ecological interface. Eur. J. Plant Pathol. 138:529-547.

Ali, A., and Roossinck, M. J. 2017. Analysis of quasispecies variation in single and mixed viral infection. Virus Evol. 3:1-7.

Backus, E. A., Cline, A. R., Ellerseick, M. R., and Serrano, M. S. 2007. Lygus hesperus (Hemiptera: Miridae) feeding on cotton: New methods and parameters for analysis of nonsequential electrical penetration graph data. Ann. Entomol. Soc. Am. 100:296-310.

Bourdin, D., and Lecoq, H. 1991. Evidence that heteroencapsidation between two potyviruses is involved in aphid transmission of a non-aphidtransmissible isolate from mixed infections. Phytopathology 81:1459-1464.

Bragard, C., Caciagli, P., Lemaire, O., Lopez-Moya, J. J., MacFarlane, S., Peters, D., Susi, P., and Torrance, L. 2013. Status and prospects of plant virus control through interference with vector transmission. Annu. Rev. Phytopathol. 51:177-201.

Carmo-Sousa, M., Moreno, A., Garzo, E., and Fereres, A. 2014. A nonpersistently transmitted-virus induces a pull-push strategy in its aphid vector to optimize transmission and spread. Virus Res. 186:38-46.

Célix, A., López-Sese, A., Almarza, N., Gómez-Guillamón, M. L., and Rodriguez-Cerezo, E. 1996. Characterization of Cucurbit yellow stunting disorder virus, a Bemisia tabaci-transmitted closterovirus. Phytopathology 86:1370-1376.

Chávez-Calvillo, G., Contreras-Paredes, C. A., Mora-Macias, J., Noa-Carrazana, J. C., Serrano-Rubio, A. A., Dinkova, T. D., Carrillo-Tripp, M., and Silva-Rosales, L. 2016. Antagonism or synergism between papaya ringspot virus and papaya mosaic virus in Carica papaya is determined by their order of infection. Virology 489:179-191.

Chen, G., Su, Q., Shi, X., Pan, H., Jiao, X., and Zhang, Y. 2018. Persistently transmitted viruses restrict the transmission of other viruses by affecting their vectors. Front. Physiol. 9:1261.

Collar, J. L., Avilla, C., and Fereres, A. 1997. New correlations between aphid stylet paths and nonpersistent virus transmission. Environ. Entomol. 26: 537-544.

Culver, J. N., and Padmanabhan, M. S. 2007. Virus-induced disease: Altering host physiology one interaction at a time. Annu. Rev. Phytopathol. 45: 221-243.

DaPalma, T., Doonan, B. P., Trager, N. M., and Kasman, L. M. 2010. A systematic approach to virus-virus interactions. Virus Res. 149:1-9. 
Desbiez, C., Joannon, B., Wipf-Scheibel, C., Chandeysson, C., and Lecoq, H. 2011. Recombination in natural populations of watermelon mosaic virus: New agronomic threat or damp squib? J. Gen. Virol. 92:1939-1948

Desbiez, C., and Lecoq, H. 2004. The nucleotide sequence of Watermelon mosaic virus (WMV, Potyvirus) reveals interspecific recombination between two related potyviruses in the $5^{\prime}$ part of the genome. Arch. Virol. 149:1619-1632.

Díaz-Pendón, J. A., Fernández-Muñoz, R., Gómez-Guillamón, M. L., and Moriones, E. 2005. Inheritance of resistance to Watermelon mosaic virus in Cucumis melo that impairs virus accumulation, symptom expression, and aphid transmission. Phytopathology 95:840-846.

Eid, S., Abou-Jawdah, Y., El-Mohtar, C., Sobh, H., and Havey, M. 2006. Tolerance in cucumber to Cucurbit yellow stunting disorder virus. Plant Dis. 90:645-649.

Eigenbrode, S. D., Ding, H., Shiel, P., and Berger, P. H. 2002. Volatiles from potato plants infected with Potato leafroll virus attract and arrest the virus vector, Myzus persicae (Homoptera: Aphididae). Proc. R. Soc. B Biol. Sci. 269:455-460.

Elena, S. F., Fraile, A., and García-Arenal, F. 2014. Evolution and emergence of plant viruses. Adv. Virus Res. 88:161-191.

Escriu, F., Perry, K. L., and García-Arenal, F. 2000. Transmissibility of $\mathrm{Cu}$ cumber mosaic virus by Aphis gossypii correlates with viral accumulation and is affected by the presence of its satellite RNA. Phytopathology 90: 1068-1072.

Froissart, R., Michalakis, Y., and Blanc, S. 2002. Helper componenttranscomplementation in the vector transmission of plant viruses. Phytopathology 92:576-579.

Garzo, E., Moreno, A., Hernando, S., Mariño, V., Torne, M., Santamaria, E., Díaz, I., and Fereres, A. 2016. Electrical penetration graph technique as a tool to monitor the early stages of aphid resistance to insecticides. Pest Manage. Sci. 72:707-718.

Gil-Salas, F. M., Peters, J., Boonham, N., Cuadrado, I. M., and Janssen, D. 2012. Co-infection with Cucumber vein yellowing virus and Cucurbit yellow stunting disorder virus leading to synergism in cucumber. Plant Pathol. 61:468-478.

Gutiérrez, S., Michalakis, Y., Van Munster, M., and Blanc, S. 2013. Plant feeding by insect vectors can affect life cycle, population genetics and evolution of plant viruses. Funct. Ecol. 27:610-622.

Ingwell, L. L., Eigenbrode, S. D., and Bosque-Pérez, N. A. 2012. Plant viruses alter insect behavior to enhance their spread. Sci. Rep. 2:578.

Juarez, M., Legua, P., Mengual, C. M., Kassem, M. A., Sempere, R. N., Gómez, P., Truniger, V., and Aranda, M. A. 2013. Relative incidence, spatial distribution and genetic diversity of cucurbit viruses in eastern Spain. Ann. Appl. Biol. 162:362-370.

Lefèvre, T., Lebarbenchon, C., Gauthier-Clerc, M., Missé, D., Poulin, R., and Thomas, F. 2009. The ecological significance of manipulative parasites. Trends Ecol. Evol. 24:41-48.

Lim, H.-S., Jang, C.-Y., Bae, H.-H., Kim, J.-K., Lee, C.-H., Hong, J.-S., Ju, H.-J., Kim, H.-G., and Domier, L. L. 2011. Soybean mosaic virus infection and helper component-protease enhance accumulation of Bean pod mottle virus-specific siRNAs. Plant Pathol. J. 27:315-323.

Liu, B., Preisser, E. L., Chu, D., Pan, H., Xie, W., Wang, S., Wu, Q., Zhou, X., and Zhang, Y. 2013. Multiple forms of vector manipulation by a plantinfecting virus: Bemisia tabaci and Tomato yellow leaf curl virus. J. Virol. 87:4929-4937.

Marco, C. F., Aguilar, J. M., Abad, J., Gómez-Guillamón, M. L., and Aranda, M. 2003. Melon Resistance to Cucurbit yellow stunting disorder virus is characterized by reduced virus accumulation. Phytopathology 93:844-852.

Más, P., and Pallás, V. 1995. Non-isotopic tissue-printing hybridization: A new technique to study long-distance plant virus movement. J. Virol. Methods 52:317-326.

Mascia, T., and Gallitelli, D. 2016. Synergies and antagonisms in virus interactions. Plant Sci. 252:176-192.

Mauck, K., Bosque-Pérez, N. A., Eigenbrode, S. D., De Moraes, C. M., and Mescher, M. C. 2012. Transmission mechanisms shape pathogen effects on host-vector interactions: Evidence from plant viruses. Funct. Ecol. 26: $1162-1175$.

Mauck, K. E. 2016. Variation in virus effects on host plant phenotypes and insect vector behavior: What can it teach us about virus evolution? Curr. Opin. Virol. 21:114-123.

Mauck, K. E., Chesnais, Q., and Shapiro, L. R. 2018. Evolutionary determinants of host and vector manipulation by plant viruses. Adv. Virus Res. 101: 189-250.

Mauck, K. E., De Moraes, C. M., and Mescher, M. C. 2010. Deceptive chemical signals induced by a plant virus attract insect vectors to inferior hosts. Proc. Natl. Acad. Sci. U.S.A. 107:3600-3605

Mauck, K. E., De Moraes, C. M., and Mescher, M. C. 2015a. Infection of host plants by Cucumber mosaic virus increases the susceptibility of Myzus persicae aphids to the parasitoid Aphidius colemani. Sci. Rep. 5:10963.
Mauck, K. E., Smyers, E., De Moraes, C. M., and Mescher, M. C. 2015b. Virus infection influences host plant interactions with non-vector herbivores and predators. Funct. Ecol. 29:662-673.

Mingot, A., Valli, A., Rodamilans, B., San León, D., Baulcombe, D. C., García, J. A., and López-Moya, J. J. 2016. The P1N-PISPO trans-frame gene of Sweet potato feathery mottle potyvirus is produced during virus infection and functions as an RNA silencing suppressor. J. Virol. 90:3543-3557.

Moreno, A., Tjallingii, W. F., Fernandez-Mata, G., and Fereres, A. 2012. Differences in the mechanism of inoculation between a semi-persistent and a non-persistent aphid-transmitted plant virus. J. Gen. Virol. 93:662-667.

Murphy, J. F., and Bowen, K. L. 2006. Synergistic disease in pepper caused by the mixed infection of Cucumber mosaic virus and Pepper mottle virus. Phytopathology 96:240-247.

Navas-Castillo, J., López-Moya, J. J., and Aranda, M. A. 2014. Whiteflytransmitted RNA viruses that affect intensive vegetable production. Ann. Appl. Biol. 165:155-171.

Oerke, E.-C. 2006. Crop losses to pests. J. Agric. Sci. 144:31-43.

Peñaflor, M. F. G. V., Mauck, K. E., Alves, K. J., De Moraes, C. M., and Mescher, M. C. 2016. Effects of single and mixed infections of Bean pod mottle virus and Soybean mosaic virus on host-plant chemistry and hostvector interactions. Funct. Ecol. 30:1648-1659.

Perry, K. L., and Francki, R. I. B. 1992. Insect-mediated transmission of mixed and reassorted cucumovirus genomic RNAs. J. Gen. Virol. 73:2105-2114.

Petek, M., Rotter, A., Kogovšek, P., Baebler, S., Mithöfer, A., and Gruden, K. 2014. Potato virus $Y$ infection hinders potato defence response and renders plants more vulnerable to Colorado potato beetle attack. Mol. Ecol. 23: 5378-5391.

Rochow, W. F. 1972. The role of mixed infections in the transmission of plant viruses by aphids. Annu. Rev. Phytopathol. 10:101-124.

Rodríguez-López, M. J., Garzo, E., Bonani, J. P., Fernández-Muñoz, R., Moriones, E., and Fereres, A. 2012. Acylsucrose-producing tomato plants forces Bemisia tabaci to shift its preferred settling and feeding site. PLoS One 7:e33064.

Roossinck, M. J., Martin, D. P., and Roumagnac, P. 2015. Plant virus metagenomics: Advances in virus discovery. Phytopathology 105:716-727.

Roossinck, M. J., Saha, P., Wiley, G. B., Quan, J., White, J. D., Lai, H., Chavarría, F., Shen, G., and Roe, B. A. 2010. Ecogenomics: Using massively parallel pyrosequencing to understand virus ecology. Mol. Ecol. 19:81-88.

Ruiz-Ferrer, V., Boskovic, J., Alfonso, C., Rivas, G., Llorca, O., López-Abella, D., and López-Moya, J. J. 2005. Structural analysis of tobacco etch potyvirus HC-Pro oligomers involved in aphid transmission. J. Virol. 79: 3758-3765.

Saldaña, J., Elena, S. F., and Solé, R. V. 2003. Coinfection and superinfection in RNA virus populations: A selection-mutation model. Math. Biosci. 183: $135-160$

Salvaudon, L., De Moraes, C. M., and Mescher, M. C. 2013. Outcomes of coinfection by two potyviruses: Implications for the evolution of manipulative strategies. Proc. R. Soc. B Biol. Sci. 280:20122959.

Sarria, E., Cid, M., Garzo, E., and Fereres, A. 2009. Excel Workbook for automatic parameter calculation of EPG data. Comput. Electron.Agric. 67:35-42.

Savenkov, E. I., and Valkonen, J. P. 2001. Potyviral helper-component proteinase expressed in transgenic plants enhances titers of Potato leaf roll virus but does not alleviate its phloem limitation. Virology 283:285-293.

Shapiro, L., De Moraes, C. M., Stephenson, A. G., and Mescher, M. C. 2012. Pathogen effects on vegetative and floral odours mediate vector attraction and host exposure in a complex pathosystem. Ecol. Lett. 15:1430-1438.

Shapiro, L. R., Salvaudon, L., Mauck, K. E., Pulido, H., De Moraes, C. M., Stephenson, A. G., and Mescher, M. C. 2013. Disease interactions in a shared host plant: Effects of pre-existing viral infection on cucurbit plant defense responses and resistance to bacterial wilt disease. PLoS One 8: e77393.

Stafford, C. A., Walker, G. P., and Ullman, D. E. 2011. Infection with a plant virus modifies vector feeding behavior. Proc. Natl. Acad.Sci. U.S.A. 108: 9350-9355.

Stout, M. J., Thaler, J. S., and Thomma, B. P. H. J. 2006. Plant-mediated interactions between pathogenic microorganisms and herbivorous arthropods. Annu. Rev. Entomol. 51:663-689.

Su, Q., Preisser, E. L., Zhou, X. M., Xie, W., Liu, B. M., Wang, S. L., Wu, Q. J., and Zhang, Y. J. 2015. Manipulation of host quality and defense by a plant virus improves performance of whitefly vectors. J. Econ. Entomol. 108:11-19.

Sufrin-Ringwald, T., and Lapidot, M. 2011. Characterization of a synergistic interaction between two cucurbit-infecting begomoviruses: Squash leaf curl virus and Watermelon chlorotic stunt virus. Phytopathology 101:281-289.

Syller, J. 2012. Facilitative and antagonistic interactions between plant viruses in mixed infections. Mol. Plant Pathol. 13:204-216.

Syller, J. 2014. Biological and molecular events associated with simultaneous transmission of plant viruses by invertebrate and fungal vectors. Mol. Plant Pathol. 15:417-426. 
Syller, J., and Grupa, A. 2016. Antagonistic within-host interactions between plant viruses: Molecular basis and impact on viral and host fitness. Mol. Plant Pathol. 17:769-782.

Tjallingii, W. F. 1978. Electronic recording of penetration behaviour by aphids. Entomol. Exp. Appl. 24:721-730.

Tjallingii, W. F. 1988. Electrical recording of stylet penetration activities. Pages 95-108 in: Aphids: Their Biology, Natural Enemies and Control, Vol. 28. A. K. Minks and P. J. Harrewijn, eds. Elsevier Science Publishers, Amsterdam, The Netherlands.

Tollenaere, C., Susi, H., and Laine, A. L. 2016. Evolutionary and epidemiological implications of multiple infection in plants. Trends Plant Sci. 21: 80-90.

Tugume, A. K., Mukasa, S. B., and Valkonen, J. P. T. 2016. Mixed infections of four viruses, the incidence and phylogenetic relationships of Sweet potato chlorotic fleck virus (Betaflexiviridae) isolates in wild species and sweetpotatoes in Uganda and evidence of distinct isolates in East Africa. PLoS One 11:e0167769.

Valli, A., García, J. A., and López-Moya, J. J. 2015. Potyviridae. Pages 1-10 in: Encyclopedia of Life Sciences. John Wiley \& Sons, Ltd., Chichester, U.K.

Valli, A. A., Gallo, A., Rodamilans, B., López-Moya, J. J., and García, J. A. 2018. The HCPro from the Potyviridae family: An enviable multitasking helper component that every virus would like to have. Mol. Plant Pathol. 19:744-763.

van Munster, M., Yvon, M., Vile, D., Dader, B., Fereres, A., and Blanc, S. 2017. Water deficit enhances the transmission of plant viruses by insect vectors. PLoS One 12:e0174398.
Wang, J., Turina, M., Medina, V., and Falk, B. W. 2009. Synergistic interaction between the Potyvirus, Turnip mosaic virus and the Crinivirus, Lettuce infectious yellows virus in plants and protoplasts. Virus Res. 144:163-170.

Westwood, J. H., Lewsey, M. G., Murphy, A. M., Tungadi, T., Bates, A., Gilligan, C. A., and Carr, J. P. 2014. Interference with jasmonic acidregulated gene expression is a general property of viral suppressors of RNA silencing but only partly explains virus-induced changes in plant-aphid interactions. J. Gen. Virol. 95:733-739.

Whitfield, A. E., Falk, B. W., and Rotenberg, D. 2015. Insect vector-mediated transmission of plant viruses. Virology 479-480:278-289.

Wintermantel, W. M., Gilbertson, R. L., McCreight, J. D., and Natwick, E. T. 2016. Host-specific relationship between virus titer and whitefly transmission of Cucurbit yellow stunting disorder virus. Plant Dis. 100:92-98.

Wintermantel, W. M., Gilbertson, R. L., Natwick, E. T., and McCreight, J. D. 2017. Emergence and epidemiology of Cucurbit yellow stunting disorder virus in the American Desert Southwest, and development of host plant resistance in melon. Virus Res. 241:213-219.

Zhang, T., Luan, J.-B., Qi, J.-F., Huang, C.-J., Li, M., Zhou, X.-P., and Liu, S.-S. 2012. Begomovirus-whitefly mutualism is achieved through repression of plant defences by a virus pathogenicity factor. Mol. Ecol. 21: 1294-1304.

Zinga, I., Chiroleu, F., Legg, J., Lefeuvre, P., Komba, E. K., Semballa, S., Yandia, S. P., Mandakombo, N. B., Reynaud, B., and Lett, J.-M. 2013. Epidemiological assessment of cassava mosaic disease in Central African Republic reveals the importance of mixed viral infection and poor health of plant cuttings. Crop Prot. 44:6-12. 